\title{
Preparation of wheat-potato-peanut composite flour cakes
}

\section{N. Akter and Md. Abdul Alim}

Department of Food Technology and Rural Industries, Bangladesh Agricultural University, Mymensingh-2202, Bangladesh

\begin{tabular}{|c|c|}
\hline ARTICLE INFO & Abstract \\
\hline $\begin{array}{l}\text { Article history: } \\
\text { Received: } 08 \text { May } 2018 \\
\text { Accepted: } 18 \text { July } 2018\end{array}$ & \multirow{3}{*}{$\begin{array}{l}\text { This study reports on the suitable formulation of cake using potato and peanut flour with wheat flour. } \\
\text { Fresh potato and peanut were analyzed for their chemical compositions and then dried in cabinet dryer. } \\
\text { Four samples of cake: containing wheat flour only; containing } 70 \% \text { wheat flour, } 5 \% \text { potato flour and } 25 \% \\
\text { peanut flour; containing } 70 \% \text { wheat flour, } 15 \% \text { potato flour and } 15 \% \text { peanut flour; and containing } 70 \% \\
\text { wheat flour, } 20 \% \text { potato flour and } 10 \% \text { peanut flour were analyzed for proximate compositions. The } \\
\text { properties of cakes were evaluated in terms of volume, moisture content, weight, and crumb and crust } \\
\text { characteristics. The prepared cake samples were also judged in categories of color, flavor, texture and } \\
\text { overall acceptability. Among the formulations, cake sample containing } 70 \% \text { wheat flour, } 15 \% \text { potato flour } \\
\text { and } 15 \% \text { peanut flour secured the highest score with respect to color, texture and overall acceptability. } \\
\text { Finally, the storage stability of the composite cake, packaged with single layer polythene, was evaluated in } \\
\text { terms of moisture uptake by storing it in room temperature }\left(25^{\circ} \mathrm{C}\right) \text {. }\end{array}$} \\
\hline $\begin{array}{l}\text { Keywords: } \\
\text { Peanut flour, cabinet dryer, } \\
\text { proximate composition, cake }\end{array}$ & \\
\hline $\begin{array}{l}\text { Correspondence: } \\
\text { Md Abdul Alim } \\
\text { (maalim07@yahoo.com) }\end{array}$ & \\
\hline
\end{tabular}

\section{Introduction}

Cake is one of the relished and palatable baked products prepared from flour, sugar, shortening, baking powder and egg as principal ingredients. Preparation of cakes from wheat flour is the conventional practice. However, in tropical countries, wheat production is limited and import of wheat flour to meet local demand is a necessity (Giami et al., 2004). Nowadays, the use of composite flour in which flour from locally grown crops replaces a portion of wheat flour is common in many developing countries. This meets the high demand for functional foods with health benefits as well as reducing the demand for imported wheat and stimulating production and use of locally grown non-wheat agricultural products (UNECA, 1985).

Wheat flour is a powder made from grinding of wheat used for human consumption. Wheat varieties are called "clean," "white," or "brown" or "hard" if they have high gluten content, and they are called "soft" or "weak" flour if gluten content is low (Chu and Michael, 2004). Hard flour, or bread flour, is high in gluten (12-14\%), and has elastic toughness that holds its shape well once baked. Soft flour is comparatively low in gluten and so results in a finer or crumbly texture. Soft flour is usually divided into cake flour, which is the lowest in gluten, and pastry flour, which has slightly more gluten than cake flour. In terms of the parts of the grain (the grass fruit) used in flour - the endosperm or protein/starchy part, the germ or protein/fat/vitamin-rich part, and the bran or fiber part - there are three general types of flour. White flour is made from the endosperm only. Whole grain or whole meal flour is made from the entire grain, including bran, endosperm and germ. Germ flour is made from the endosperm and germ, excluding the bran.
Potato flour is often confused with potato starch, but the flour is produced from the entire dehydrated potato whereas potato starch is produced from the starch only. It is also used as a thickener for soups, gravies and sauces. Potato flour is heavy and has a definite potato flavor. This flour, made from the whole potato including the skin, absorbs large amount of water. It is not used as the main flour in baking as it will absorb too much liquid and make the product gummy. Only small amounts are used to increase water, hold product together and so on. It is used as an ingredient in potato-based recipes to enhance the potato flavor and is often mixed with other types of flour for baking breads, cakes and rolls (BFF, 1996).

Peanut (Arachis hypogaea) is a species in the legume family Fabaceae, native to South America, Mexico and Central America (Gibbon and Pain, 1985). Peanuts are natural food. They are classified as a legume because they mature underground into pods or shells, which absorb nutrients from the soil. The kernels inside are recognized as nuts into tree nuts. Inside each kernel is a peanut seed. All seeds inherently have stored nutrients that, when planted, help to nourish new seedlings and bring new life (Jiang, 2002). Whether thought of as a legume or nut, peanuts and their ground butter inherently possess a complex package of nutrients known to be critical in infancy as well as in promoting long-term health.

Cakes are soft bakery products produced by baking a batter containing flour, baking powders and beaten eggs with or without shortenings. According to the final products desired, other ingredients such as flavorings, nuts, chocolate and dried fruits are also included. Cakes are a major snack in the fast food industry and highlight of many celebrations. They are highly cherished by 
women and children. It is a complete food, rich in fat and proteins. There are literally millions of cake recipes and can be classified based on their main ingredients such as coffee cakes, occasion cakes or based primarily on ingredients and cooking techniques (Eke et al., 2008). Cake may be small and intended for individual consumption such as queen cake, while longer cakes are cut, sliced and served as part of a meal or social functions. The purpose of the study is to evaluate the quality of composite flour cake incorporating wheat, potato and peanut flours and to assess the shelf-life of processed cake.

\section{Materials and Methods}

Good quality commercial wheat flour (Brand: Teer Maida) was collected from local market, and potato and peanut flours were prepared in the laboratory of the Department of Food Technology and Rural Industries under the Faculty of Agricultural Engineering and Technology, Bangladesh Agricultural University, Mymensingh. All other necessary ingredients and chemicals were used from laboratory stocks. The potatoes were cleaned and washed using potable water and peeled. They were cut into $3 \mathrm{~mm}$ slices, blanched, dried and used for further processing. The process of preparing potato flour is described in Fig.1.The peanuts were dried in cabinet dryer, peeled, grinded and used for further processing. The schematic diagram for preparation of peanut flour is shown in Fig. 2.

\section{Chemical analysis of potato, peanut and wheat flour}

The potato, peanut and wheat flour were analyzed for moisture content, protein, ash, crude fat, crude fiber and total carbohydrate. All the determinations were done in triplicate and the results were expressed as the average value. Moisture content, protein content, ash content, fat content and crude fiber were determined adopting AOAC (2005) method. The carbohydrate content was determined by subtracting the measured moisture, ash, protein and fat content from 100 (Pearson, 1970).

\section{Formulation and preparation of composite cake}

The basic formulation for plain cake (multi-stage mixing) and composite flour cakes are outlined in Table 1 (Atkins, 1971; Anon, 2000). The replacements of wheat flour in the formulations were made with different levels of composite flour. Cakes were prepared by replacing wheat flour with different levels of composite flour in the basic formulation of cake (Table 1) as per the methods of Rajchel et al., (1975). The wheat, potato and peanut flours, and other ingredients for each cake sample were weighed. The flours were mixed together according to the percentages givenin Table 1 . Then sugar and shortening were mixed in a mixing machine for 20 minutes to produce a cream. At later stages, one egg and other ingredients, and, finally, the mixed flour were added and mixed well using a mixer at low speed (145 rpm) for 10 minutes to ensure even distribution of the components. The bowl was scrapped and stirred for an additional two minutes at medium speed (250 rpm). Then another egg was added, and the mixture was stirred at low speed for two minutes. After the bowl was scrapped, the mixture was stirred an additional two minutes at medium speed. Then a portion of batter was scaled into pre-greased cake pan. All cakes were baked in air oven for 45 minutes at $170^{\circ} \mathrm{C}$. The schematic diagram for preparation of composite cake is shown in Fig. 3.

Table 1. Basic formulation of control and composite flour cake (100 $\mathrm{g}$ flour basis)

\begin{tabular}{lcccc}
\hline Ingredients & \multicolumn{4}{c}{ Cake samples } \\
\cline { 2 - 5 } & $\mathrm{S}_{0}$ & $\mathrm{~S}_{1}$ & $\mathrm{~S}_{2}$ & $\mathrm{~S}_{3}$ \\
\hline Wheat flour (g) & 100 & 70 & 70 & 70 \\
Potato flour (g) & - & 5 & 15 & 25 \\
Peanut flour (g) & - & 25 & 15 & 5 \\
Sugar (g) & 85 & 85 & 85 & 85 \\
Oil (g) & 70 & 70 & 70 & 70 \\
Baking powder (g) & 3.5 & 3.5 & 3.5 & 3.5 \\
Powder milk (g) & 25 & 25 & 25 & 25 \\
Salt (g) & 2 & 2 & 2 & 2 \\
Egg (no.) & 2 & 2 & 2 & 2 \\
\hline
\end{tabular}

\section{Objective analysis of cakes}

The cake samples $\mathrm{S}_{0}$ (control cake), $\mathrm{S}_{1}$ (70\% wheat flour, $5 \%$ potato flour\& $25 \%$ peanut flour), $S_{2}(70 \%$ wheat flour, $15 \%$ potato flour\& $15 \%$ peanut flour) and $\mathrm{S}_{3}$ (70\% wheat flour, $20 \%$ potato flour\& $10 \%$ peanut flour) were analyzed for moisture content, protein, ash, crude fat and crude fiber as per the methods of AOAC (2005) and total carbohydrate content as per Pearson (1970). Cake volume was initially used as an important parameter of cake quality. It was determined by seed displacement method (Ott, 1987). Moisture content was determined according to the methods outlined in AOAC (2005). The weights and specific volumes of baked cakes were also measured.

\section{Subjective (sensory) evaluation of cakes}

The symmetry and characteristics of crust and crumb of the cakes supplemented with wheat, potato and peanut flour samples were evaluated and recorded. Cakes were evaluated organoleptically for color, flavor, texture and overall acceptability. A 1-9-point hedonic rating test (Appendix I-V) was also performed to assess the degree of acceptability of cakes containing different levels of potato and peanut flour. One slice from each lot of cake was presented to 10 panelists as randomly coded samples. The taste panelists were asked to rate the sample for color, flavor, texture and overall acceptability on a 1-9-point scale where, 1 = dislike extremely, 2 = dislike very much, $3=$ dislike moderately, $4=$ dislike slightly, 5 = neither like nor dislike, 6 = like slightly, 7 = like moderately, 8 = like very much, $9=$ like extremely. The results were evaluated by analysis of variance and Duncan's New Multiple Range Test procedures of the Statistical Analysis system (SAS, 1985). 


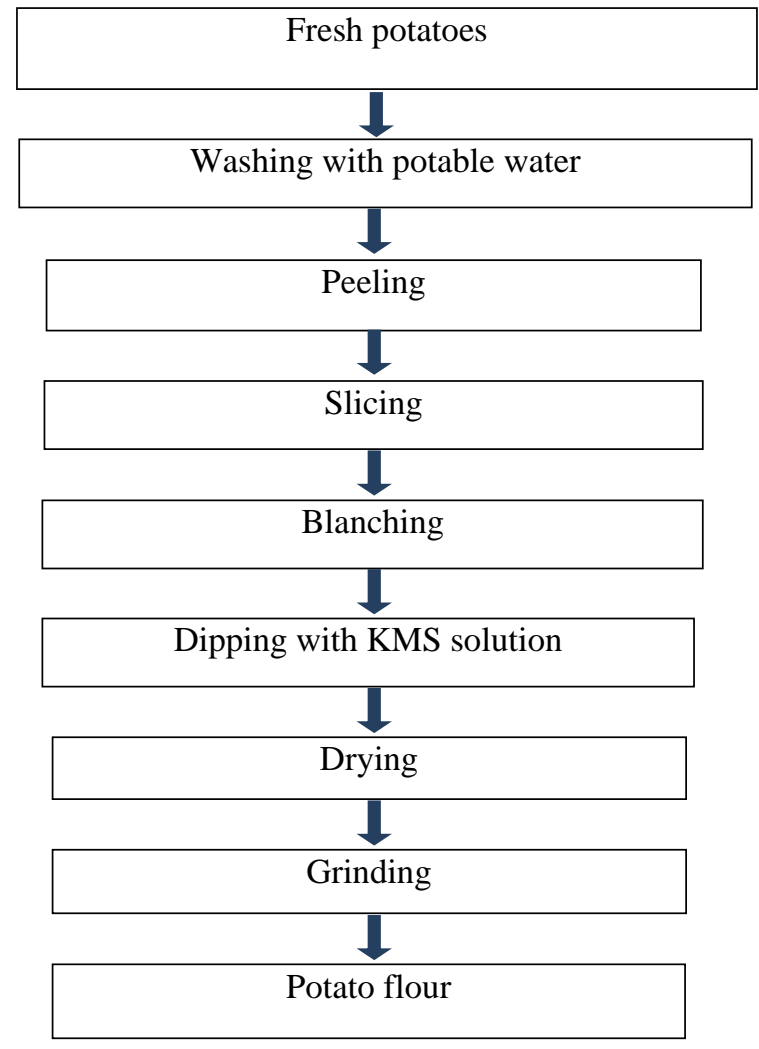

Fig. 1. Schematic diagram for preparation of potato flour

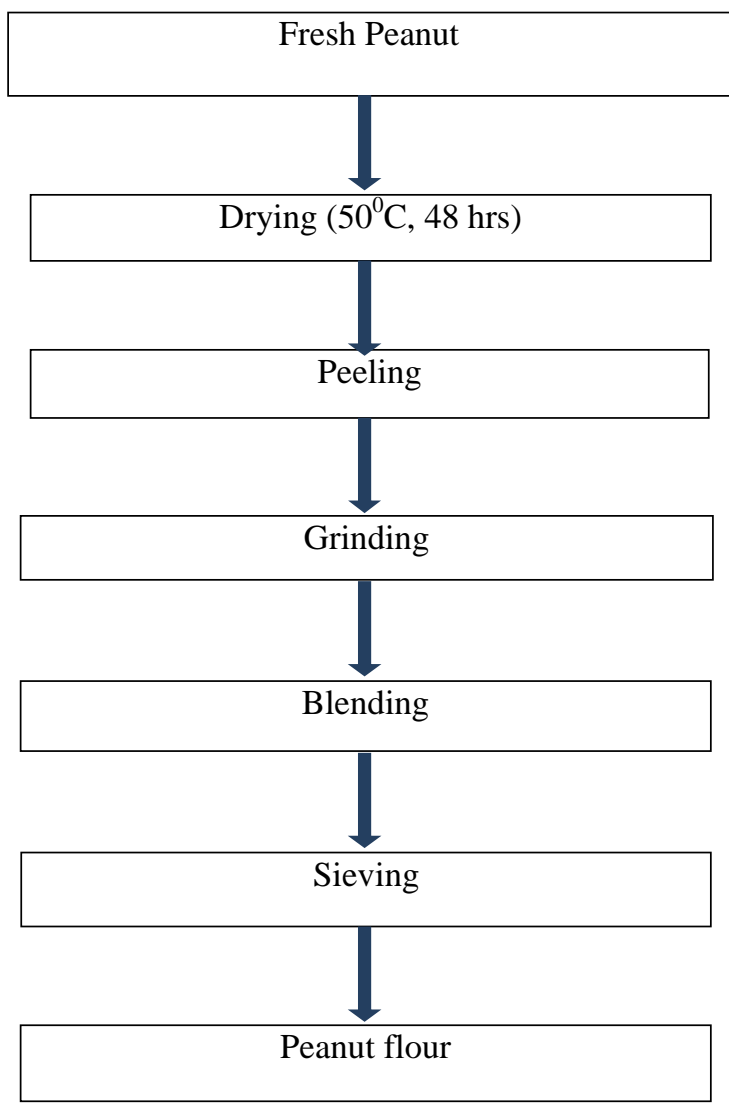

Fig. 2. Schematic diagram for preparation of peanut flour

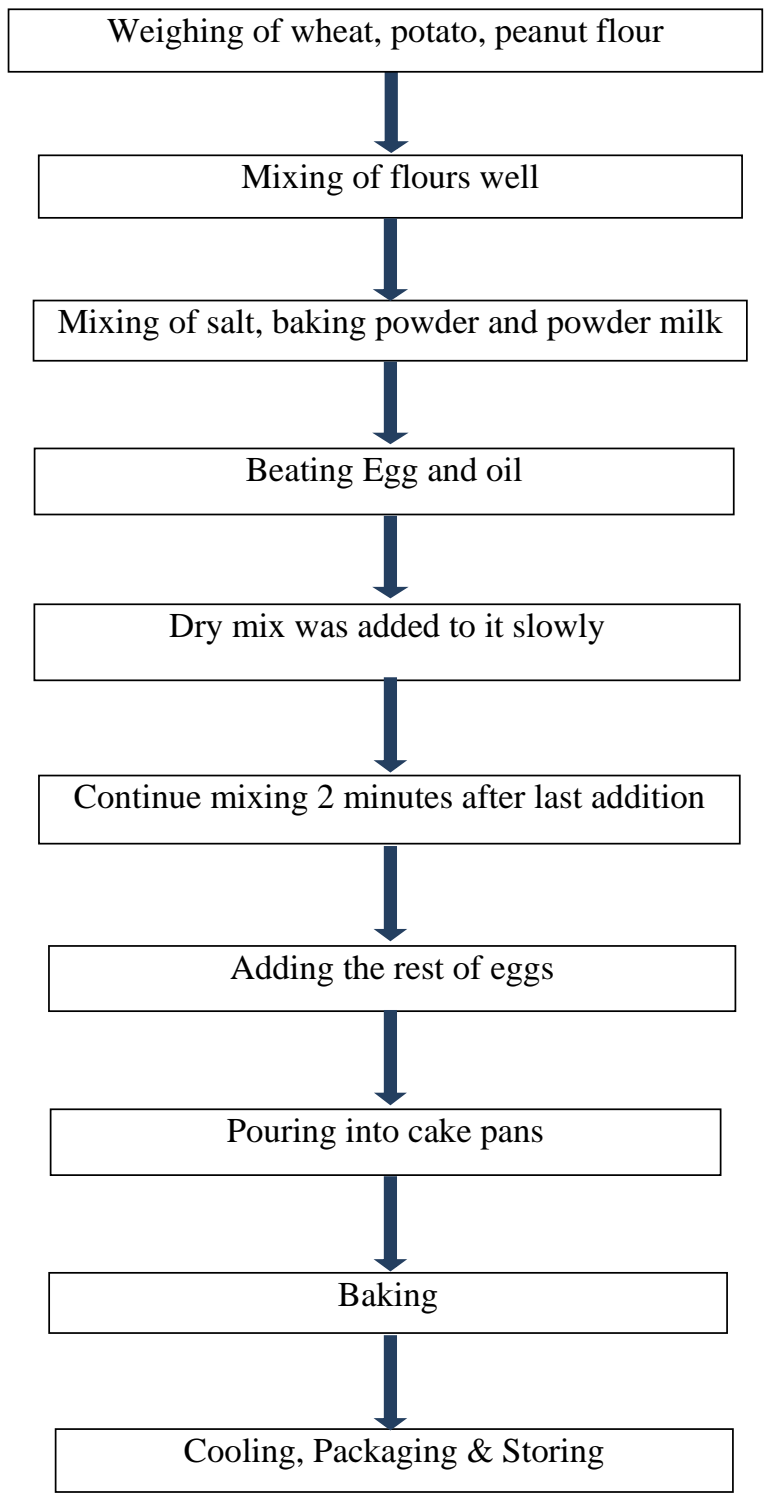

Fig. 3. Schematic diagram for preparation of composite cake

Observation on storage stability of composite cake The storage stability of different composite cakes was observed at various storage conditions in terms of moisture gain. Each ten (10) gram sample was packed with single layer high density polythene and stored at room temperature $\left(25^{\circ} \mathrm{C}\right)$ and refrigeration temperature $\left(5^{\circ} \mathrm{C}\right)$. The moisture uptake by composite cakes at every day was determined gravimetrically.

\section{Results and Discussion}

Proximate compositions of potato and peanut

The potato contained moisture $75 \%$, protein $2.0 \%$, fat $2.1 \%$, ash $2.2 \%$, crude fiber $18.70 \%$ and total carbohydrates $19.0 \%$ by wet weight basis (Table 2). Ahmed and Afaf (2010) reported proximate composition of potato as water $75.17 \%$, protein $1.60 \%$, fat $0.50 \%$, ash $0.83 \%$ and total carbohydrate $21.47 \%$ by wet weight basis. The peanut contained moisture $7.40 \%$, protein $24.27 \%$, fat $46.10 \%$, ash $1.48 \%$, crude fiber $2.83 \%$ and total carbohydrates $17.41 \%$. 
Table 2. Composition of potato and peanut in wet weight basis (wb) and dry weight basis $(\mathrm{db})$

\begin{tabular}{lccc}
\hline \multicolumn{1}{c}{ Components } & & Potato & Peanut \\
\hline Moisture (\%) & $\mathrm{wb}$ & 75.0 & 7.40 \\
& $\mathrm{db}$ & 300.0 & 7.99 \\
Protein (\%) & $\mathrm{wb}$ & 2.0 & 24.27 \\
& $\mathrm{db}$ & 8.0 & 26.21 \\
Fat (\%) & $\mathrm{wb}$ & 2.1 & 46.10 \\
& $\mathrm{db}$ & 8.40 & 49.80 \\
Ash (\%) & $\mathrm{wb}$ & 2.2 & 1.48 \\
& $\mathrm{db}$ & 8.80 & 1.59 \\
Crude fiber (\%) & $\mathrm{wb}$ & 18.7 & 2.83 \\
& $\mathrm{db}$ & 74.80 & 3.06 \\
Total & $\mathrm{wb}$ & 19.0 & 17.41 \\
carbohydrate(\%) & $\mathrm{db}$ & 76.0 & 18.8 \\
\hline
\end{tabular}

Proximate compositions of wheat, potato and peanut flours

The results of the proximate composition of wheat, potato and peanut flours are presented in Table 3 . Wheat flour contained moisture $13.04 \%$ and $14.99 \%$, protein $12.48 \%$ and $14.35 \%$, fat $0.78 \%$ and $0.89 \%$, ash $0.77 \%$ and $0.88 \%$, crude fiber $0.43 \%$ and $0.49 \%$ and total carbohydrates $72.93 \%$ and $83.87 \%$ by wet weight basis and dry weight basis, respectively. The composition of wheat flour under study was like those reported by Samuel (1960). He reported the composition of wheat flour were as: moisture $14 \%$, protein $11.25 \%$, fat $1.0 \%$, ash $0.5 \%$, crude fiber $0.4 \%$ and total carbohydrates $72 \%$. The potato flour contained moisture $14.72 \%$ and $17.26 \%$, protein $5.95 \%$ and $6.90 \%$, fat $0.98 \%$ and $1.15 \%$, ash $2.64 \% 3.09 \%$, crude fiber $4.29 \%$ and $5.03 \%$ and total carbohydrates $75.71 \%$ and $88.78 \%$ by wet weight basis and dry weight basis, respectively. The peanut flour contained moisture $1.67 \%$ and $1.69 \%$, protein $20.31 \%$ and $20.65 \%$, fat $53.65 \%$ and $54.67 \%$, ash $2.10 \%$ and $2.14 \%$, crude fiber $0.94 \%$ and $0.96 \%$ and total carbohydrates $22.17 \%$ and $28.48 \%$ by wet weight basis and dry weight basis, respectively. These results were compared with USDA (1997), which reported that peanut flour contained moisture $1.05 \%$, protein $27.55 \%$, fat $61.40 \%$, ash $3.41 \%$, crude fiber $1.25 \%$ and total carbohydrates $25.85 \%$. The small variations observed in the data may be due to the varietal differences and quality, agro-ecological condition, fertilizer use, extent of drying, storage conditions, methods of analysis, etc. By dry basis, it was observed that peanut flour contained the highest amount of protein and fat than that of wheat and potato flour; potato flour contained the highest amount of moisture, ash and crude fiber than that of wheat and peanut flour; and wheat flour contained the highest amount of total carbohydrate than that of peanut and potato flour.

\section{Physical properties of cake}

Volume of cakes: The cake volume is the most important physical quality parameter used for the evaluation of cake. It is a quantitative measurement and correlates well with dough handling properties, crumb, texture, freshness and technological versatility (Pomeranz, 1980). The volumes of cakes prepared with different levels of composite flour are presented in Table 4. It is observed the composite cake samples (from $\mathrm{S}_{1}$ to $\mathrm{S}_{3}$ ) gradually decreased with increasing level of potato flour and decreasing level of peanut flour in composite flour of dough. This might be because the potato flour contained higher percentage of fiber than that of wheat and peanut flours as well as peanut flour contained higher percentage of fat than that of wheat and potato flours. A significant impact of fiber is to reduce dough gas retention and of fat is to increase dough gas retention (Williams and Pullen, 1998). Thus, the cake volume decreased with increasing fiber percentage (from $S_{1}$ to $S_{3}$ ) and the cake volume increased with increasing fat percentage (from $S_{3}$ to $S_{1}$ ).

Table 3. Chemical compositions of wheat, potato and peanut flours

\begin{tabular}{lccc}
\hline Components & $\begin{array}{c}\text { Wheat } \\
\text { flour (\%) }\end{array}$ & $\begin{array}{c}\text { Potato } \\
\text { flour (\%) }\end{array}$ & $\begin{array}{c}\text { Peanut flour } \\
(\%)\end{array}$ \\
\hline Moisture & 13.04 & 14.72 & 1.67 \\
Protein & 12.48 & 5.95 & 20.31 \\
Fat & 0.78 & 0.98 & 53.75 \\
Ash & 0.77 & 2.64 & 2.10 \\
Crude fiber & 0.43 & 4.29 & 0.94 \\
Total & 72.93 & 75.71 & 22.17 \\
carbohydrate & & & \\
\hline
\end{tabular}

Weight of cakes: The cakes with different levels of composite flour reached higher weights (23.3-29.2g) than the control cake (23.3g) prepared from wheat flour only (Table 4). It was also observed that the weights of the composite cake samples (from $S_{1}$ to $S_{3}$ ) gradually increased with increasing the level of potato flour in composite flour of dough. This might be because potato flour contains higher percentage of fiber than that of wheat and peanut. The fiber holds the water, which contributed to the higher weight of the composite flour cake (Cauvain and Cyster, 1996).

Table 4. Effects of volume, weight, specific volume and moisture content on composite cake

\begin{tabular}{ccccc}
\hline $\begin{array}{c}\text { Cake } \\
\text { sample }\end{array}$ & $\begin{array}{c}\text { Volume } \\
\left(\mathrm{cm}^{3}\right)\end{array}$ & $\begin{array}{c}\text { Weight } \\
(\mathrm{g})\end{array}$ & $\begin{array}{c}\text { Specific volume } \\
\left(\mathrm{cm}^{3} / \mathrm{g}\right)\end{array}$ & $\begin{array}{c}\text { Moisture } \\
\text { content }(\%)\end{array}$ \\
\hline$* \mathrm{~S}_{0}$ & 80 & 23.3 & 3.43 & 12.11 \\
$\mathrm{~S}_{1}$ & 80 & 24.3 & 3.29 & 12.23 \\
$\mathrm{~S}_{2}$ & 55 & 27.1 & 2.03 & 13.45 \\
$\mathrm{~S}_{3}$ & 45 & 27.2 & 1.54 & 15.13 \\
\hline
\end{tabular}

* $\mathrm{S}_{0}=$ Control sample (with only wheat flour); $\mathrm{S}_{1}=$ Containing $70 \%$ wheat flour, $5 \%$ potato flour\& $25 \%$ peanut flour; $S_{2}=$ Containing $70 \%$ wheat flour, $15 \%$ potato flour\& $15 \%$ peanut flour; $\mathrm{S}_{3}=$ Containing $70 \%$ wheat flour, $25 \%$ potato flour\& $5 \%$ peanut flour

Specific volumes of cakes: The specific volumes of cakes prepared with different levels of composite flour in the formulation of cake are presented in Table 4. It was observed that the specific volumes among the composite cake samples (from $\mathrm{S}_{1}$ to $\mathrm{S}_{3}$ ) gradually decreased with increasing level of potato flour and 
decreasing level of peanut flour in composite flour dough. The fiber content increased as well as the fat content decreased from sample $S_{1}$ to $S_{3}$. The weight increased while volume decreased of the composite cakes (Williams and Pullen, 1998). The specific volume (cc/g) gradually decreased among the composite cakes.

Moisture contents of cakes: The cakes with different levels of composite flour obtained higher moisture contents (12.11-15.13\%) than the cake prepared from wheat flour only (12.11\%). It was observed that the moisture content of the composite cake samples (from $\mathrm{S}_{1}$ to $\mathrm{S}_{3}$ ) gradually increased with increasing level of potato flour in composite flour dough. This might be because the potato flour contained higher percentage of fiber than that of wheat and peanut. The fiber may hold the water, which might contribute to the higher moisture content of the composite flour cake (Cauvain and Young, 1996).

\section{Crust characteristics}

Color of crust: Color differences of cakes containing different levels of composite flour relative to the control are given in Table 5 . The crust color of the cake sample $\mathrm{S}_{3}$ (containing $70 \%$ wheat flour, $20 \%$ potato flour $\& 10 \%$ peanut flour) was deeper than those of control cake and other cake samples.

Consistency of crust: This term applies to the condition of the crust and varies with the types of cakes (Table 5). The overall crust characteristics of sample $S_{3}$ seemed to be better than other samples $\left(S_{1}\right.$ and $\left.S_{2}\right)$.

\section{Crumb characteristics of cakes}

Color of crumb: As compared in Table 5, sample $S_{3}$ (containing $70 \%$ wheat flour, $20 \%$ potato flour $\& 10 \%$ peanut flour) gained better crumb color than those obtained from cakes of different levels of composite flour.

Crumb texture: Crumb textures of the cakes containing various levels of composite flour are presented in Table 5. Texture differences were observed between control cake and sample $\mathrm{S}_{3}$ (containing $20 \%$ potato \& $10 \%$ peanut flour). The differences decreased with decreasing the substitution levels of potato flour. A perfect texture should be free from lumps and hardness and has smooth silky surfaces (Raffaela, 2005), which were obtained in sample $S_{1}$.

Crumb flavor: The flavor differences of cake containing different levels of composite flour relative to control are provided in Table 5. The acceptable flavor (i.e. fresh, sweet, natural, appetizing) was found in cake sample $\mathrm{S}_{3}$ (containing $70 \%$ wheat flour, $20 \%$ potato flour\& $10 \%$ peanut flour).

Crumb grain: Crumb grain of cakes indicates to the shape, size and character of the cell wall structure of crumb. The crumb grain of $S_{3}$ sample was uniform and thin walled cells as compared to other cake samples.

\section{Comparison between the compositions of cakes}

The moisture contents of four different cake samples processed with different levels of composite flour are compared in Table 6. The composition of the prepared cake samples were also calculated by material balance. The highest moisture content obtained was $15.13 \%$ (wb) and $15.76 \%(\mathrm{wb})$ based on experiment and calculated value, respectively; these were found in sample $S_{3}$. It was seen that the moisture content gradually increased from samples $S_{1}$ to $S_{3}$ with the increase of substitution levels of potato flour in composite flour. Moisture content had 4 to $10 \%$ difference, which may be due to experimental error when maintaining moisture content in laboratory. The compositions of the prepared cake samples were also calculated by material balance. The protein contents of the control sample by experimental and calculation process were in the range of $8.00 \%-$ $8.57 \%$ and $11.68-12.09 \%$, respectively in wet weight basis for all samples. Difference in protein content took place due to increasing heat due to which Millard reaction might occurred; Millard reactions occur when protein and sugars are broken down and rearranged by high temperature (Pascual et al., 2002). It may be also caused for protein denaturation. The fat contents in composite cake samples decreased (from $S_{1}$ to $S_{3}$ ) with increasing substitution level of potato flour and decreasing substitution level of peanut flour in composite. The ash (mineral) contents of four different cake samples processed with different levels of composite flour are given in Table 6. It was observed that ash content in composite cake sample $\mathrm{S}_{1}$ became higher than the control sample both wet weight basis and dry weight basis. The crude fiber contents of four different cake samples processed with different levels of composite flour are compared in Table 6. It was observed that fiber contents in composite cake samples increased (from $S_{1}$ to $S_{3}$ ) with increasing substitution level of potato flour and decreasing substitution level of peanut flour in composite dough. The variations in the carbohydrate content among cake samples under study (Table 6) might have resulted from the difference in the level of protein, fat, ash and moisture content.

\section{Sensory evaluation}

The mean score for color, flavor, texture and overall acceptability preference are presented in Table 7 . The finding indicates that the cake sample $S_{2}$ scored better color acceptability among all the cakes. The cake sample $\mathrm{S}_{3}$ scored higher flavor acceptability than all other cake samples, while the control cake sample $S_{0}$ scored the least flavor acceptability as compared to the other cake samples. The cake sample $S_{2}$ gained the highest score among cake samples for texture. The DMRT test for overall acceptability revealed that cake sample $S_{2}$ secured the highest score.

\section{Storage stability of wheat-potato-peanut composite cake}

The moisture contents at different storage durations of the sample $S_{2}$ are given in Table 8 . The results indicated that the storage stability of composite cake is 4 to 5 days at room temperature $\left(25^{\circ} \mathrm{C}\right)$ packed with single layer polythene. 
Table 5. Effects of control and composite flour cakes on crust and crumb characteristics

\begin{tabular}{|c|c|c|c|c|c|c|c|c|}
\hline \multirow{3}{*}{$\begin{array}{l}\text { Cake } \\
\text { sample }\end{array}$} & \multicolumn{2}{|c|}{ Crust characteristics } & \multicolumn{6}{|c|}{ Crumb characteristics } \\
\hline & \multirow[b]{2}{*}{ Color } & \multirow[b]{2}{*}{ Consistency } & \multirow[b]{2}{*}{ Color } & \multicolumn{2}{|c|}{ Texture } & \multirow[b]{2}{*}{ Flavor } & \multicolumn{2}{|c|}{ Grain } \\
\hline & & & & $\begin{array}{c}\text { Lums\& } \\
\text { hardness }\end{array}$ & Surface & & $\begin{array}{c}\text { Close or } \\
\text { airy }\end{array}$ & $\begin{array}{l}\text { Shape and } \\
\text { size }\end{array}$ \\
\hline$* \mathrm{~S}_{0}$ & $\begin{array}{l}\text { Light } \\
\text { brown }\end{array}$ & Tender & $\begin{array}{l}\text { White } \\
\text { yellow }\end{array}$ & Free & $\begin{array}{c}\text { Smooth } \\
\text { silky }\end{array}$ & Appetizing & Close & Uniform \\
\hline $\mathrm{S}_{1}$ & Brownish & Medium tender & Yellowish & Free & Smooth & Slightly fresh & Close & Uniform \\
\hline $\mathrm{S}_{2}$ & Brown & Tender & $\begin{array}{l}\text { Slightly } \\
\text { yellow }\end{array}$ & Slightly free & $\begin{array}{l}\text { Light } \\
\text { smooth }\end{array}$ & Appetizing & Close & Uniform \\
\hline $\mathrm{S}_{3}$ & $\begin{array}{l}\text { Deep } \\
\text { brown }\end{array}$ & Medium tough & $\begin{array}{c}\text { Deep } \\
\text { yellow }\end{array}$ & Present & Rough & Sweet & Less airy & $\begin{array}{c}\text { Less } \\
\text { uniform }\end{array}$ \\
\hline
\end{tabular}

$* \mathrm{~S}_{0}=$ Control sample (with only wheat flour); $\mathrm{S}_{1}=$ Containing $70 \%$ wheat flour, $5 \%$ potato flour\& $25 \%$ peanut flour; $\mathrm{S}_{2}=$ Containing $70 \%$ wheat flour, $15 \%$ potato flour\& $15 \%$ peanut flour; $\mathrm{S}_{3}=$ Containing $70 \%$ wheat flour, $25 \%$ potato flour\& $5 \%$ peanut flour

Table 6. Comparison between the compositions of cakes containing different levels of composite flour from experimental chemical analysis and material balance

\begin{tabular}{|c|c|c|c|c|c|c|c|c|c|}
\hline \multirow{3}{*}{$\begin{array}{c}\text { Component } \\
\text { (\%) }\end{array}$} & & \multicolumn{8}{|c|}{ Cake Sample } \\
\hline & & \multicolumn{2}{|c|}{$* \mathrm{~S}_{0}$} & \multicolumn{2}{|c|}{$\mathrm{S}_{1}$} & \multicolumn{2}{|c|}{$\mathrm{S}_{2}$} & \multicolumn{2}{|c|}{$\mathrm{S}_{3}$} \\
\hline & & Exp. & Cal. & Exp. & Cal. & Exp. & Cal. & Exp. & Cal. \\
\hline \multirow[t]{2}{*}{ Moisture } & $\mathrm{wb}$ & 12.11 & 13.22 & 12.23 & 13.68 & 13.45 & 13.92 & 15.13 & 15.76 \\
\hline & $\mathrm{db}$ & 13.78 & 15.23 & 13.93 & 15.64 & 15.54 & 16.17 & 17.82 & 18.70 \\
\hline \multirow[t]{2}{*}{ Protein } & wb & 8.14 & 11.10 & 8.57 & 12.09 & 8.19 & 11.97 & 8.00 & 11.68 \\
\hline & $\mathrm{db}$ & 9.26 & 12.79 & 9.88 & 14.00 & 9.46 & 13.90 & 9.23 & 13.86 \\
\hline \multirow[t]{2}{*}{ Fat } & wb & 22.53 & 22.26 & 27.98 & 27.19 & 26.37 & 26.82 & 25.26 & 25.13 \\
\hline & $\mathrm{db}$ & 25.63 & 26.12 & 32.25 & 31.49 & 30.47 & 31.15 & 29.76 & 29.83 \\
\hline \multirow[t]{2}{*}{ Ash } & wb & 1.32 & 1.86 & 1.70 & 1.97 & 1.24 & 1.91 & 1.22 & 1.83 \\
\hline & $\mathrm{db}$ & 1.50 & 2.14 & 1.94 & 2.28 & 1.43 & 2.22 & 1.44 & 2.17 \\
\hline \multirow[t]{2}{*}{ Crude fiber } & wb & 0.45 & 0.41 & 0.49 & 0.49 & 0.61 & 0.58 & 0.63 & 0.65 \\
\hline & $\mathrm{db}$ & 0.51 & 0.48 & 0.56 & 0.57 & 0.70 & 0.67 & 0.74 & 0.77 \\
\hline \multirow[t]{2}{*}{ Total Carbohydrate } & wb & 55.90 & 51.56 & 49.52 & 45.07 & 50.75 & 42.73 & 48.39 & 40.33 \\
\hline & $\mathrm{db}$ & 126.76 & 104.44 & 98.10 & 82.05 & 103.04 & 74.61 & 93.76 & 67.59 \\
\hline
\end{tabular}

* $\mathrm{S}_{0}=$ Control sample (with only wheat flour); $\mathrm{S}_{1}=$ Containing $70 \%$ wheat flour, $5 \%$ potato flour\& $25 \%$ peanut flour; $\mathrm{S}_{2}=$ Containing $70 \%$ wheat flour, $15 \%$ potato flour\& $15 \%$ peanut flour; $S_{3}=$ Containing $70 \%$ wheat flour, $20 \%$ potato flour\& $10 \%$ peanut flour

Table 7. Mean sensory score of control cake and composite flour cakes

\begin{tabular}{lcccc}
\hline Cake type & \multicolumn{3}{c}{ Sensory attributes } \\
\cline { 2 - 5 } & Color & Flavor & Texture & Overall acceptability \\
\hline $\mathrm{S}_{0}{ }^{*}$ & $7.5^{\mathrm{AB}}$ & $7.6^{\mathrm{B}}$ & $7.7^{\mathrm{A}}$ & $7.4^{\mathrm{BC}}$ \\
$\mathrm{S}_{1}$ & $7.8^{\mathrm{A}}$ & $7.9^{\mathrm{B}}$ & $7.8^{\mathrm{A}}$ & $7.7^{\mathrm{AB}}$ \\
$\mathrm{S}_{2}$ & $8.0^{\mathrm{A}}$ & $8.4^{\mathrm{A}}$ & $7.9^{\mathrm{A}}$ & $8.1^{\mathrm{A}}$ \\
$\mathrm{S}_{3}$ & $6.8^{\mathrm{B}}$ & $8.5^{\mathrm{A}}$ & $6.8^{\mathrm{B}}$ & $7.1^{\mathrm{C}}$ \\
LSD $(\mathrm{P}<0.05)$ & 0.7381 & 0.4864 & 0.4933 & 0.5521 \\
\hline
\end{tabular}

${ }^{*} \mathrm{~S}_{0}=$ (with only wheat flour); $\mathrm{S}_{1}=$ (containing $70 \%$ wheat flour, $5 \%$ potato flour\& $25 \%$ peanut flour); $\mathrm{S}_{2}=($ containing $70 \%$ wheat flour, $15 \%$ potato flour \& 15\% peanut flour) and $\mathrm{S}_{3}=$ (containing $70 \%$ wheat flour, $20 \%$ potato flour \& $10 \%$ peanut flour)

Table 8. Effect of atmospheric temperature on moisture content of composite cakes

\begin{tabular}{cc}
\hline Storage time (day) & Moisture content (\%)at room temperature $\left(25^{0} \mathrm{C}\right)$ \\
\hline $1^{\text {st }}$ & 13.45 \\
$2^{\text {nd }}$ & 15.23 \\
$3^{\text {rd }}$ & 16.95 \\
$4^{\text {th }}$ & 17.31 \\
$5^{\text {th }}$ & 19.05 \\
$6^{\text {th }}$ & 19.55 \\
$7^{\text {th }}$ & 19.59 \\
$8^{\text {th }}$ & 19.65 \\
$9^{\text {th }}$ & 19.91 \\
$1^{\text {th }}$ & 19.93 \\
\hline
\end{tabular}




\section{Conclusion}

The main finding of the study is that the cake sample containing $70 \%$ wheat, $15 \%$ potato and $15 \%$ peanut flours is the best in performance in regard to chemical qualities and panel evaluation. It is therefore concluded that the market value of potato and peanut can be increased through this product; increased market value will have positive impact on national economy. This study, however, did not conduct detailed analysis of nutritional constituents and functional properties of composite flour cake. So, further studies need to address these issues.

\section{References}

Ahmed, E. and Afaf, M. 2010. Nutritional situation of potato (Alpha) to Sudanese cooking method. Journal of Applied Sciences Research 6(8) 980-984.

Anon, M. A. 2000. Study on mixing characteristics of baking products. Journal of Food Processing \& Technology 4(9) 1-4.

AOAC. 2005. Official Methods of Food Analysis. Association of Official Analytical Chemists, $15^{\text {th }}$ edition, Washington D.C.

Atkins, J. H. C. 1971. Mixing requirement of baked products, Food manufacture. Bangladesh Research publication. 47120.

BFF (Barry Farm Foods). 1996: Barry Farm Foods, A seminar in Barry Farm Foods on utilization of potato flour. USA.

Cauvain, S. P. and Cyster, J. A. 1996. Sponge Cake Technology, CCFRA Review No. 2. CCFRA, Chipping, Campden, UK.5465.

Chu, M. and Michael, E. H. 2004. Wheat flour, Cooking for engineers. Journal of Agriculture and Food Industry.56-59.

Eke, J., Achinewhu, S. C. and Sanni, L. 2008. Nutritional and sensory qualities of some Nigerian cakes. Journal of Nigerian Food 26(2) $12-13$.
Giami, S. Y., Amasisi, T. and Ekiyor, G. 2004: Comparison of bread making properties of composite flour from kernels of roasted and boiled African breadfruit (Treculia africanadecne) seeds. Journal of Raw Material Research 1(8) 16-25.

Gibbon, and Pain. 1985. The formation of dough and bread structures. The ability of starch to form structures and the improving effect of glycerol monostearate. Journal of Cereal Chemistry 38(2)140-152.

Jiang, R. 2002. Nut and peanut butter consumption and risk of type 2 diabetes in women. Journal of the American Medical Association 288(20) 2554-2560.

Ott, D. B. 1987. Applied Food Science Laboratory Manual. Michigan State University, Pergramon Press,U.S.A.38.

Pascual, E. C., Goodman, B. A. and Yeretzian, C. 2002. A new mechanism of the Maillard Reaction involving sugar fragmentation. American Chemical Society. Journal of Agricultural Food Chemistry 50 6114-6122

Pearson, D. 1970. The Chemical Analysis of Foods. 7th Ed. Churchill Livingstone, New York 112 (1) 72-89.

Pomeranz, Y. 1980. What? How Much? What function? In bread making. Cereal Foods World 25 656-662.

Raffaela, P. 2005. Australian Good Taste. American Society for microbiology. 70

Rajchel, C. L., Zabik, M. E. and Everson, E. 1975. Wheat bran and middlings. A source of dietary fiber in banana, chocolate, nut and spices cakes. Bakers Dig., 49 27-30.

Samuel, J. H. 1960. Food Control its Public-health Aspects. Chapman and Hall Ltd, London 470

SAS. 1985. SAS users guide: Statistics, Version 5th ed. SAS Institute Inc., Cary, NC.

UNECA. 1985. Technical compendium on composite flours. Ethiopia: United Nations Economic Commission for Africa 67-81.

USDA. 1997. U.S. Department of Agriculture and Agricultural Research Service. USDA Nutrient Database for Standard References, Nutrient Data Laboratory Home.

Williams, T. and Pullen, G. 1998. Functional ingredients. In: Technology of Bread Making (eds S.P. Cauvain and L.S. Young), Blackie Academic \& Professional, London 45-80. 